\title{
The costs and benefits of biological control of invasive alien plants in South Africa
}

\author{
B.W. van Wilgen* \& W.J. De Lange \\ Centre for Invasion Biology, CSIR Natural Resources and the Environment, P.O. Box 320, Stellenbosch, 7599 South Africa
}

\begin{abstract}
This paper provides a brief review of the environmental and economic costs of invasive alien plants in South Africa as a background to assessments of returns on investment in weed biological control. The understanding of impacts and their economic costs is far from perfect, but estimates indicate that some costs (of lost water, grazing and biodiversity) are currently about R6.5 billion per annum (about $0.3 \%$ of South Africa's GDP of around R2000 billion: $\mathrm{R} 7=$ about US\$1), and could rise to $>5 \%$ of GDP if invasive plants are allowed to reach their full potential. By comparing the costs of biological control research and implementation to the benefits of restored ecosystem services, or avoided costs, and avoided ongoing control costs, biological control has been shown to be extremely beneficial in economic terms: estimated benefit:cost ratios ranged from 8:1 up to 3726:1. Currently, spending on biological control is far lower than on other forms of control (about $5 \%$ and $14 \%$ of that spent on mechanical and chemical control, respectively), despite the significantly better returns on investment from biological control. In aggregate these assessments indicate that higher levels of spending on biological control research would generate extremely attractive returns on investment.
\end{abstract}

Key words: water resources, ecosystem services, benefit:cost ratios.

\section{INTRODUCTION}

Invasive alien plants are a large and growing environmental problem in South Africa (van Wilgen \& Richardson 2010) where they negatively impact on biodiversity and the delivery of ecosystem services. To reduce their impacts, invasive alien plants (or 'weeds') are managed by appropriate combinations of mechanical clearing, the application of herbicides, and biological control, i.e. integrated control. Biological control involves the use of introduced agents (plant-feeding insects and mites, and plant pathogens) with the aim of reducing the fecundity, 'fitness' and 'invasiveness' of the target weeds, to bring about declining populations and reductions in the rate of spread of the problem plants. Biological control can provide complete control of the problem plant, or else augment and reduce the need for herbicidal controls and mechanical clearing. As a management practice, the biological control of weeds is an attractive option because: (i) it is relatively cheap and very safe compared with the costs and risks associated with herbicide development and deployment; (ii) it can be successfully integrated with other management practices; and (iii) it is self-sustaining.

Internationally, there has been a protracted

*To whom correspondence should be addressed.

E-mail: bvwilgen@csir.co.za debate about the safety of weed biological control and its possible impacts on non-target species (e.g. Louda et al. 2003; Sheppard et al. 2005). The pragmatic attitude adopted in South Africa is summarized by Moran et al. (2005): 'The introduction and release of weed biological control agents is inherently risky. Therefore, all reasonable efforts must be made to determine the host preferences and the safety of the agents, and the possible impacts and benefits, prior to their release. However, because of the overwhelming threat of IAPs [invasive alien plants] to the South African environment and to the well-being of its people, and given the limited financial and human resources available, biological control should be considered an option in all management programmes against IAPs even if there are some attendant risks. Sustained longterm suppression of most IAPs will not be possible without the intervention of biological control...'.

In practice, since 1913, 271 agent taxa, i.e. species, subspecies, and biotypes, have been introduced into South Africa for testing: $40 \%$ of these were eventually deemed to be safe according to the official regulations that were current at the time (Klein et al. 2011), and were released. About $40 \%$ of the introduced taxa were rejected by researchers or have been shelved because of concerns about their safety; and $20 \%$ are still in quarantine undergoing 
further stringent testing (Klein 2011). Crucially, during all this time there have never been any reports of introduced biological control agents in South Africa that have significantly damaged any crop plants or native species (Moran et al. 2005).

The growing problem of invasive alien plants has recently led to a growth in research that seeks to quantify their environmental and economic impacts, both in South Africa (Turpie 2004), and globally (Perrings et al. 2010). Programmes of integrated control are expensive, and information on potential cost savings are needed by conservationists, who need to optimise the use of scarce funds; policy-makers, who need to make comparisons with other potential uses of public funds, in particular; and managers, who need to direct scarce funds to projects that will optimise returns. Part of this broader focus has included attempts to quantify the benefits of biological control in environmental and economic terms.

This paper is a review of the environmental and economic costs of invasive alien plants in South Africa, as a background to assessments of returns on investment in biological control. It compares the costs of biological control to other forms of control, and provides a review of studies that have sought to compare these costs with the economic benefits that they generate. The focus is on alien plants that invade untransformed natural ecosystems, and it excludes alien plants that are weeds in crop or plantation situations.

\section{THE COSTS OF ALIEN PLANT INVASIONS}

\section{Current environmental impacts}

Invasions by alien plants change the composition and functioning of ecosystems, and impact on the delivery of ecosystem services. In order to estimate the costs of invasions, it is first necessary to identify and quantify the full range of ecosystem services that are delivered, and secondly to estimate the degree to which these are reduced by invasions. Reliable economic estimates of the costs of alien plant invasions therefore require an understanding of the above two elements, but their extent and magnitude have only been partially quantified in South Africa (Richardson \& van Wilgen 2004). Some of the impacts for which information is available are discussed briefly below.

Water resources. The effects of invasive alien trees and shrubs on surface water resources have been identified as a major impact in South Africa (Le Maitre et al. 2000; Görgens \& van Wilgen 2004). It has been estimated that invading alien plants cover 10 million ha in South Africa, and, annually, use 3.3 billion $\mathrm{m}^{3}$ of water in excess of that used by native vegetation (about $6.7 \%$ of the water runoff in the entire country, with the losses being concentrated in invaded parts of the fynbos and grassland biomes, and along invaded riparian zones). This estimate is based on coarse mapping, and models that make a number of assumptions, and therefore has to be treated as no more than preliminary (Le Maitre et al. 2000). The models in question were derived from the results of experiments that sought to establish the effects of afforestation with alien trees, particularly species in the genus Pinus (Pinaceae), using the assumption that invasion of natural vegetation by similar species was analogous to afforestation (Le Maitre et al. 1996). Floating aquatic weeds, including Azolla filiculoides Lam. (Azollaceae), Eichhornia crassipes (C.Mart.) Solms (Pontederiaceae) and Salvinia molesta D.S. Mitch. (Salviniaceae), invade dams, reservoirs and freshwater ecosystems, where they impact negatively on water quality, and economic and recreational activities

Grazing resources. Invasive alien plants have significant effects on grazing resources. Rangelands that are utilized by both domestic livestock and wildlife have become invaded by several alien plant species in the 20th century. In arid parts of the country, invasive mesquite trees, Prosopis species (Fabaceae), form dense stands of thinstemmed and relatively stunted trees that exclude livestock and reduce herbaceous ground cover (Zimmermann 1991). Opuntia aurantiaca Lindl. (Cactaceae) currently occupies about 1.9 million ha in South Africa, where it impedes livestock production (van Wilgen et al. 2004). The list of invasive species that increasingly impact on rangelands continues to grow: examples include Chromolaena odorata (L.) R.M.King \& H.Rob. (Asteraceae), Solanum elaeagnifolium Cav. (Solanaceae), and Campuloclinium macrocephalum (Less.) DC. (Asteraceae).

Biodiversity. The impacts of invasive species on biodiversity in South Africa are probably severe, but not well documented. Most South African research on alien plant impacts has focused at small spatial scales (plots or communities), and much of this work has been in the fynbos (Mediterranean-climate shrubland) biome of the Cape Floral Kingdom (Cowling et al. 1997; Latimer et al. 2004; Richardson \& van Wilgen 2004). This research has 
shown that dense stands of alien trees and shrubs in fynbos can rapidly reduce abundance and diversity of native plants at the scale of small plots. Studies from other biomes have produced only scattered information on impacts. In arid savannas, the widespread replacement of native Acacia-dominated communities by alien Prosopis species has been shown to reduce bird species richness and diversity (Dean et al. 2002), as well as the numbers of dung beetle species (Steenkamp \& Chown 1996). In mesic savannas, C. odorata invasions can change native spider abundance, assemblage patterns, diversity and estimated species richness (Mgobozi et al. 2008), and in riparian situations $C$. odorata increases shading on riverbanks, leading to altered sex ratios of native Nile crocodiles (Leslie \& Spotila 2001).

Fire intensity and erosion. Invasion of grasslands and shrublands by tall trees and shrubs increases the amount of plant material (fuel) that can burn. Typical sites invaded by alien trees have up to 10 times more fuel than pristine sites, $10-25$ tonnes compared to 2-5 tonnes per hectare (van Wilgen \& Richardson 1985). While ecosystems in South Africa are normally resilient to regular burning, these increased fuel loads lead to higher intensity fires and a range of related, detrimental effects. Fire intensities in normal grassland or fynbos, range from $200-5000 \mathrm{~kW} / \mathrm{m}$ : indications are that fire intensities in stands of invading plants can be as high as $50000 \mathrm{~kW} / \mathrm{m}$ (van Wilgen \& Richardson 1985). Physical damage to the soil can occur, resulting in increased erosion after fire (Scott et al. 1998; Scott \& van Wyk 1990; Scott \& Schulze 1992; van Wyk 1985).

Human and animal health. Very little information is available regarding the impacts of invasive alien plant species on human and animal health. However, negative effects can be significant, as illustrated by the case of parthenium weed Parthenium hysterophorus L. (Asteraceae). This species, causes severe dermatitis, allergy and toxicity in humans, and its toxicity affects stock and crop production (Wise et al. 2007), resulting in direct economic losses.

\section{Economic costs of the environmental impacts of invasive alien plants}

Attempts to quantify the economic impacts of invasive species began in South Africa in the mid1990s, with a focus on reductions in water resources (Le Maitre et al. 1996; van Wilgen et al. 1996). These studies showed that invasive alien plants may be using as much as $6.7 \%$ of the country's runoff (Versfeld et al. 1998; Le Maitre et al. 2000); that clearing the invasive plants is a good investment, simply to prevent water loss (van Wilgen et al. 1997; Hosking \& du Preez 1999); and that failure to clear stands of invading trees will result in exponential increases in the costs of clearing as catchment areas become further invaded (Le Maitre et al. 2002). South Africa is a water-scarce country, and, in response to growing demands, water has been allocated by government to various users within water basins. On average, $98 \%$ of South Africa's existing water resources are already allocated, and in many basins are over-allocated, indicating that demand is exceeding supply. Most water thus finds economic use and is even constraining development, and wasteful losses from alien plant invasions can be ill-afforded. De Wit et al. (2001) estimated the macro-economic consequences of water losses for urban, agricultural and industrial use, and showed that the cost of clearing programmes can easily be justified in terms of the economic benefits derived from preventing water losses or from restoring them to pristine levels.

Several studies have followed the early work on water loss (Table 1). Initially, this work was carried out in the fynbos biome, where additional impacts of invasion on wildflower harvests, ecotourism, and biodiversity were considered. Studies in other biomes (see Table 1) were focused on the impacts of a single species, Acacia mearnsii De Wild. (Mimosaceae) and P. hysterophorus. All these studies concluded that the impacts were significant, and, with one exception (Hosking \& Du Preez 2004), that the cost of attempts to address the problem through clearing would be economically justifiable.

A recent study at a national scale, examined the combined effects of 56 important invasive alien plant species on three ecosystem services (water production, grazing and biodiversity) produced by South Africa's major terrestrial biomes (van Wilgen et al. 2008). A subsequent study (De Lange \& van Wilgen 2010) then expressed these impacts in monetary terms. The estimated economic losses under current levels of impact totalled R6.5 billion per annum, about $0.3 \%$ of South Africa's GDP of around R2000 billion in 2009. The bulk of estimated losses were attributable to water (R5.8 billion) with the balance to grazing (R300 million) and to other biodiversity-related values (R400 million) $(\mathrm{R} 7=$ about US\$1). 
van Wilgen \& De Lange: Costs and benefits of biological control of invasive alien plants

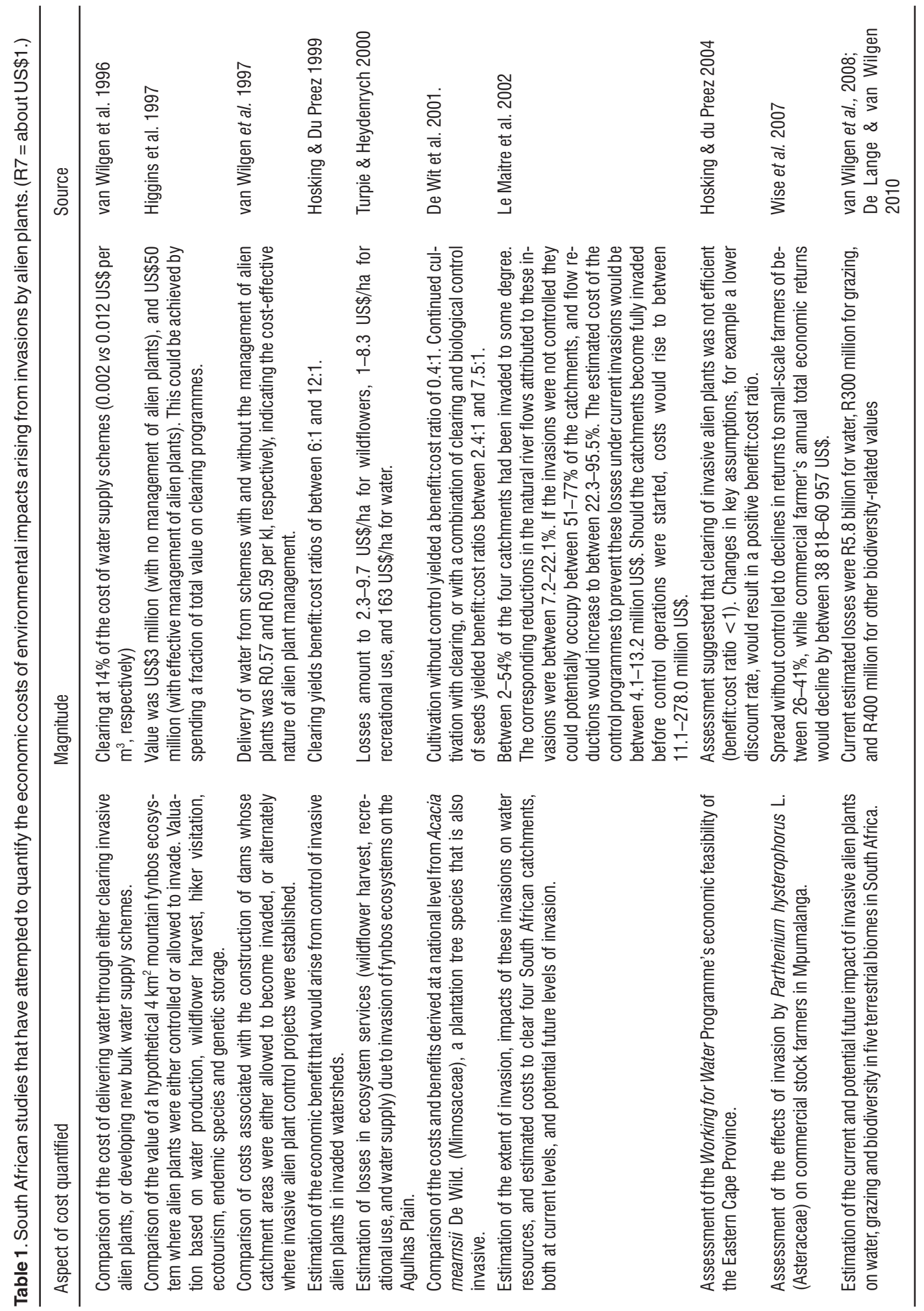


Potential future levels of impacts

Indications are that the impacts of invasive alien plants will grow in future, both because existing species have not yet occupied the full extent of their potential range, and because new species continue to arrive. At a national scale, reductions in surface water runoff as a result of current invasions are $>3000$ million $\mathrm{m}^{3}$, but the potential reductions would be more than eight times greater if invasive alien plants were to occupy the full extent of their potential range (van Wilgen et al. 2008). Reductions in grazing capacity as a result of current levels of invasion amounted to just over $1 \%$ of the potential number of livestock that could be supported. However, future impacts could increase to as high as $71 \%$ (van Wilgen et al. 2008). A 'biodiversity intactness index' (the remaining proportion of pre-modern populations) ranged from $89 \%$ to $71 \%$ for the five biomes (van Wilgen et al. 2008). Biodiversity intactness is a concept that compares the effects of a change in land use (in this case invasion by alien plants) to the reference condition of undisturbed ecosystems (Scholes \& Biggs 2005). The biodiversity intactness index (BII) is a richness and area-weighted average of co-existing populations of plants, mammals, birds, reptiles and frogs in a given area. If the population impact $\left(I_{i j k}\right)$ is defined as the relative population of taxon $i$ (as compared to the reference state) under land use activity $k$ in ecosystem $j$, then BII gives the average remaining fraction of the populations of all species considered:

$$
B I I=\frac{\sum_{i} \sum_{j} \sum_{k} R_{i j} A_{j k} I_{i j k}}{\sum_{i} \sum_{j} \sum_{k} R_{i j} A_{j k}},
$$

where $R_{i j}=$ richness (number of species) of taxon $i$ in ecosystem $j$ and where $A_{j k}=$ area of land use $k$ in ecosystem $j$.

With the exception of the fynbos biome, current invasions were estimated to have had very little impact on biodiversity intactness. Under future levels of invasion, however, these estimated intactness values decreased to around $30 \%$ for the savanna, fynbos and grassland biomes, but to even lower values (13\% and $4 \%$ ) for the two Karoo biomes, suggesting that these biomes would lose most of their component species if invasions were allowed to reach their full potential. Estimates of possible future impacts suggest that economic losses due to water, grazing and biodiversity alone could reach $5.2 \%$ of GDP for these three ecosystem services if invasive plants were not controlled .

\section{THE ECONOMIC COSTS AND BENEFITS OF BIOLOGICAL CONTROL}

The costs of biological control research have been quantified in two studies in South Africa (van Wilgen et al. 2004; De Lange \& van Wilgen 2010). Both of these studies used data on the costs of biological control research which were gathered from the major institutes that had conducted research into biological control since its inception in 1913, and both calculated a present value (PV) of the research effort. However, they are not directly comparable as the first used the year 2000, and the second the year 2008 to express PVs. Both studies included the costs of research aimed at locating, importing, screening, and releasing (where applicable) the agents, post-release monitoring, and some implementation costs (for example the release of agents at new sites, sometimes at the request of landowners or managers). They did not include the costs associated with mass-rearing and release from certain facilities that were established after 1996 by the Working for Water Programme (WfW) of the Department of Water Affairs.

The first study (van Wilgen et al. 2004) focused on six invasive alien plant species (see Table 2), while the second used 'functional groups' (as listed in Table 2) of invasive alien plants as a basis for the calculation of costs. The first study estimated that the PV of costs of biological control projects aimed at single species ranged from R700 000 for golden wattle, Acacia pycnantha Benth. (Fabaceae), to R17.3 million for Lantana camara L. (Verbenaceae), and totalled R41 million. The second study estimated the total cost of biological control research on four invasive alien plant groups as R102 million, expressed in 2008 values (De Lange \& van Wilgen 2010). The cost for individual groups covered an approximately five-fold range, from R10 million for fire-adapted trees to R50 million for subtropical shrubs.

By comparing the costs of biological control research to the benefits of restored ecosystem services or avoided impacts, and avoided ongoing control costs, biological control has been shown, in several studies in South Africa, to be extremely beneficial in economic terms (Table 2). This is both because it is relatively cheap, and because it is sustainable, yielding benefits for as long as the biological control agents remain active (which, in 


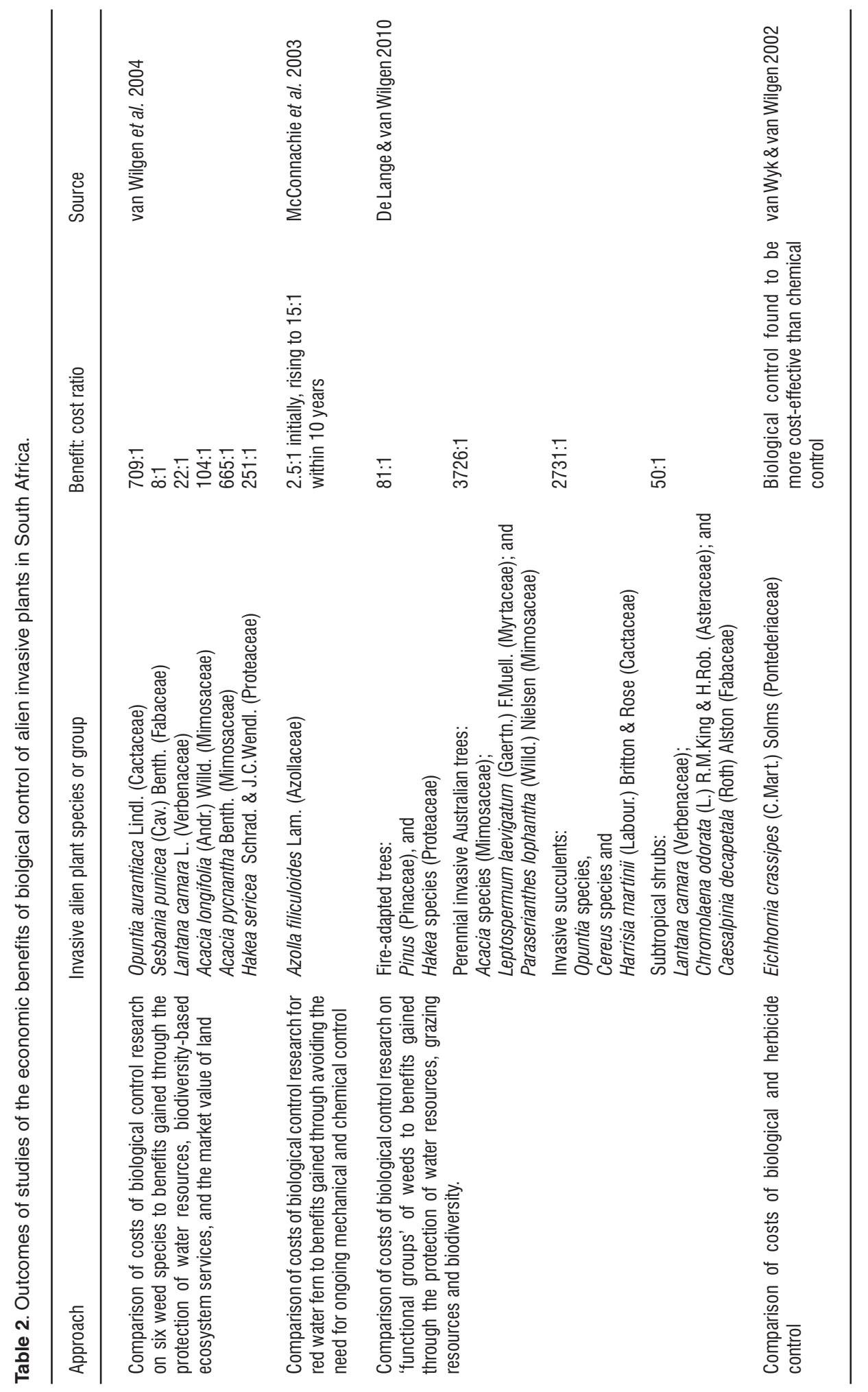


Table 3. The proportion (\% of the total) of budget line items allocated to mechanical, chemical and biological control respectively. Most ( $80 \%$ ) of wages, equipment, transport and training were assumed to be associated with mechanical control, and $20 \%$ with chemical control. Overhead costs were distributed proportionally across the three forms of control. Data are from the Working for Water annual budget for 2009/10, courtesy of C. Marais.

\begin{tabular}{|c|c|c|c|c|}
\hline Budget line items & Mechanical control & Chemical control & Biological control & Total \\
\hline $\begin{array}{l}\text { Implementation (wages for labourers, } \\
\text { equipment, transport, chemicals and training) }\end{array}$ & 42 & 22 & 3 & 67 \\
\hline $\begin{array}{l}\text { Overheads (national office costs, regional } \\
\text { office costs, and research other than biological } \\
\text { control) }\end{array}$ & 20.6 & 10.9 & 1.5 & 33 \\
\hline Total & 62.6 & 32.9 & 4.5 & 100 \\
\hline $\begin{array}{l}\text { Relative proportions (proportion of total budget } \\
\text { allocated to each form of control) }\end{array}$ & 13.9 & 7.3 & 1 & \\
\hline
\end{tabular}

many cases, is in perpetuity). Estimated benefit: cost ratios ranged from 8:1 to 3726:1, indicating remarkable savings due to investments in biological control research and implementation.

\section{Sensitivity analyses}

As these valuation models make a number of assumptions, most studies of this nature subject the results to sensitivity analyses to gauge whether the findings remain robust if key assumptions are changed. In the case of the study on six invasive alien plant species (van Wilgen et al. 2004), the sensitivity analysis revealed that the model was sensitive to changes in the estimated rate of spread of the invasive alien plant species concerned, but that the estimated returns on investment in biological control research generally remained positive with some variations between the species (negative benefit:cost ratios were only obtained for Hakea sericea Schrad. \& J.C. Wendl. (Proteaceae) and Sesbania punicea (Cav.) Benth. (Fabaceae) when spread rates were reduced to lower levels in the model). In the case of the study on plant functional groups (De Lange \& van Wilgen 2010), sensitivity analyses suggested that benefit:cost ratios remained positive even if the estimates of key variables were substantially reduced. For example, the study estimated the proportion of the overall benefit of control that was attributable to biological control, and found that this estimate could be reduced by between $98-99 \%$ without the benefit:cost ratios becoming negative. In addition, if the approximation of the area that would have been invaded had there been no control in the past (a key variable in estimating the value gained from control) was also reduced (by up to $75 \%$ ), benefit:cost ratios were still positive and remained so even when the first key variable (proportion of control attributable to biological control) was reduced by between $85-99 \%$, depending on the group of weeds. These sensitivity analyses suggest that the estimates are robust, and that a high degree of confidence can be placed on the findings that investment in biological control is economically extremely beneficial.

\section{RELATIVE FUNDING LEVELS FOR BIOLOGICAL CONTROL}

Most government expenditure on the integrated control of invasive alien plants in South Africa is channelled through the WfW Programme (Zimmermann et al. 2004). This programme has a dual focus on invasive alien plant control (to protect or restore vital ecosystem services, of which water is the most important), and on poverty alleviation (through the employment of disadvantaged people in rural areas). Currently, WfW has an annual operating budget of approximately R500 million, and the way in which this budget is subdivided provides the only available estimate of the allocation of funds to the various forms of integrated invasive alien plant control. About one third of the budget is required for programme overheads (Table 3). Other expenses associated with implementation include equipment, transport and training, and $37.7 \%$ is allocated to the wages for the workers engaged in mechanical clearing and the application of herbicides. This is in accord with the poverty-alleviation mandate of the programme. The purchase of herbicides for chemical control accounts for $10.1 \%$ of the funds, and $2.6 \%$ is allocated to biological control (C. Marais, WfW, pers. comm.). Assuming 
that $20 \%$ of implementation costs are spent on the application of herbicides, and $80 \%$ on mechanical clearing, then the allocation to the three pillars of integrated control (mechanical, chemical and biological) is roughly in the ratio of 14:7:1 (Table 3), i.e. for every one rand spent on biological control, seven are spent on chemical control and fourteen on mechanical control.

\section{DISCUSSION}

Biological control solutions will not be found for all invasive alien plant species, and even when biological control is a viable option, the degree of control achieved will not always be complete. Clearly, therefore, other forms of control will always be required and will need to be funded. However, the financial data indicate that biological control is currently under-funded compared to other forms of control, and that there is adequate justification for the proposition that a higher proportion of funding should go to biological control. Cost savings as a result of investments in biological control operations are very high, as indicated by the information in this review and certainly much higher than those from investments into other forms of control. This strongly suggests that optimal strategies to control alien plant invasions should seek to maximise the potential benefits of biological control. However, the proportion of funding allocated to biological control has not been determined with such maximization in mind. Rather, biological control endeavours have been granted a seemingly arbitrary proportion of the funds that were allocated for research activities. Mechanical and chemical forms of control, while effective in the short term, and often essential components of integrated control, are at best a holding action. Invasive alien plant species are never eradicated by mechanical and chemical clearing, and will re-invade cleared areas, requiring constant ongoing containment. The likelihood that funding for such operations can be maintained at the necessary levels in perpetuity is low. Biological control solutions therefore should be sought and implemented for as many weed species as possible, freeing up scarce resources for the control of invasive plant species for which no biological control options are available.

Funding for biological control relies heavily on political support and remains vulnerable for this reason. The estimated economic benefits of invasive alien plant control projects are not always of interest, or attractive, to those in a position to make decisions about funding. This is opposed to, for example, the interest and support derived from the politically attractive employment benefits that arise from mechanical control. There are a number of reasons for this. The benefits of alien plant control, especially those in natural (rather than agricultural) environments are largely 'public good' benefits. In such cases, the individual marginal benefit (the amount of benefit gained by any one person) is small. Where individual marginal benefits are small, people tend not to take them seriously, despite the total benefit being very large (as there are many people). In cases where public goods are to be protected, government, and not the private sector, supplies the funding. South Africa's newly-elected government was quick to see the benefits of job creation for the rural poor, and this explains the high levels of funding for these labour-intensive activities (van Wilgen et al. 2011). Many of the projected benefits of alien plant control also come about from avoiding future impacts rather than from removing current impacts (for example, by preventing further spread of a weed species that has not yet reached its full potential). People find it difficult to appreciate the value of avoidance of future impacts that are not yet manifesting themselves, and are thus not inclined to assign a priority for funding projects in this category. This is especially true in the case of the rural poor, who are forced to heavily discount the future in favour of meeting today's basic needs.

The impacts associated with invasive alien plants are often felt most by those who can least afford them. These include poor people in rural areas who rely more heavily on ecosystem services such as water, grazing and harvesting of natural products. The introduction of biological control to prevent growth in, or reverse, these impacts is therefore in the best interests of the poor communities that government is striving to help. It is clear that this message has not been effectively communicated and translated into higher levels of funding for biological control research. Such communication should be recognised as a high priority by the biological control research community, as they are best qualified to provide it.

These problems are not restricted to biological control, but are pervasive across most activities relating to environmental conservation. The tradi- 
tional arguments for conservation seldom make a compelling case for the correlation between conservation and social welfare. This has led to the widespread perception that environmental conservation is a luxury that can only be afforded once the more important needs relating to social welfare have been addressed. Although in South Africa there is a progressive interpretation of sustainable development in the country's constitution, and this is further recognised in environmental legislation, including the provisions of the National Water Act and the National Environmental Management Act, the link between this progressive legislative intention, and action, as embodied in the current government's Accelerated and Shared Growth Initiative for South Africa (ASGISA) is not effectively implemented. The basis of social development embodied by ASGISA is driven by consumerism, and it places little emphasis on the resilience of social-ecological systems (Burns \& Hattingh 2006). These tendencies continue despite growing evidence that environmental assets are indispensable for pro-poor economic growth strategies such as ASGISA. The failure to make the link between socio-economic wellbeing, on the one hand, and environmental

\section{REFERENCES}

BURNS, M. \& HATTINGH, J. 2006. Locating policy within the taxonomy of sustainable development. South African Journal of Environmental Law and Policy 13: $1-24$.

COWLING, R.M., RICHARDSON, D.M. \& PIERCE, S.M. (Eds). 1997. Vegetation in Southern Africa. Cambridge University Press, Cambridge, U.K.

DEAN, W.R.J., ANDERSON, M.D., MILTON, S.J. \& ANDERSON, T.A. 2002. Avian assemblages in native Acacia and alien Prosopis drainage line woodland in the Kalahari, South Africa. Journal of Arid Environments 51: 1-19.

DE LANGE, W.J. \& VAN WILGEN, B.W. 2010. An economic assessment of the contribution of biological control to the management of invasive alien plants and to the protection of ecosystem services in South Africa. Biological Invasions 12: 4113-4124

DE WIT, M., CROOKES, D. \& VAN WILGEN, B.W. 2001. Conflicts of interest in environmental management: estimating the costs and benefits of a tree invasion. Biological Invasions 3: 167-178.

GÖRGENS, A.H.M. \& VAN WILGEN, B.W. 2004. Invasive alien plants and water resources: an assessment of current understanding, predictive ability and research challenges. South African Journal of Science 100: 27-34.

HIGGINS, S.I., TURPIE, J.K., COSTANZA, R., COWLING, R.M., LE MAITRE, D.C., MARAIS, C. \& MIDGLEY, G.F. 1997. An ecological economic simula- security, on the other, continues to drive practices that at best favour the former over the latter, and at worst see them as conflicting.

A re-examination of these concepts in the light of the evidence reviewed in this paper would favour a larger allocation of funding to biological control. Finally, the practice of biological control is classified by the major funding agencies as research, instead of (more appropriately) as an essential component of integrated alien plant management. Research budgets are notoriously vulnerable to funding cuts in times of shortage, as they are regarded as non-essential. For this to change, the essential nature and cost-effectiveness of biological control needs to be communicated more effectively. The studies described here provide the starting point for the development of cogent arguments in support of this enhanced funding.

\section{ACKNOWLEDGEMENTS}

Funding for the preparation of this review was provided by the Council for Scientific and Industrial Research, the Working for Water Programme of the South African Department of Water Affairs, and the DST/NRF Centre for Invasion Biology, Stellenbosch University.

tion model of mountain fynbos ecosystems: Dynamics, valuation and management. Ecological Economics 22: $155-169$.

HOSKING, S.G. \& DU PREEZ, M. 1999. A cost-benefit analysis of removing alien trees in the Tsitsikamma mountain catchment. South African Journal of Science 95: 442-448.

HOSKING, S.G. \& DU PREEZ, M. 2004. A cost-benefit analysis of the Working for Water Programme on selected sites in South Africa. Water SA 30: 143-152.

KLEIN, H. 2011. A catalogue of the insects, mites and pathogens that have been used or rejected, or are under consideration, for the biological control of invasive alien plants in South Africa. African Entomology 19: 515-549.

KLEIN, H., HILL, M.P., ZACHARIADES, C. \& ZIMMERMANN, H.G. 2011. The regulation of biological control agent importations and releases against invasive alien plants in South Africa. African Entomology 19: 488-497.

LATIMER, A.M., SILANDER, J.A., GELFAND, A.E., ROBELO, A.G. \& RICHARDSON, D.M. 2004. Quantifying threats to biodiversity from invasive alien plants and other factors: a case study from the Cape Floristic Region. South African Journal of Science 100: 81-86.

LE MAITRE, D.C., VAN WILGEN, B.W., CHAPMAN, R.A. \& McKELLY, D.H. 1996. Invasive plants and water resources in the Western Cape Province, South 
Africa: modelling the consequences of a lack of management. Journal of Applied Ecology 33: 161-172.

LE MAITRE, D.C., VAN WILGEN, B.W., GELDERBLOM, C.M., BAILEY, C., CHAPMAN, R.A. \& NEL, J.A. 2002. Invasive alien trees and water resources in South Africa: case studies of the costs and benefits of management. Forest Ecology and Management 160: 143-159.

LE MAITRE, D.C., VERSFELD, D.B. \& CHAPMAN, R.A. 2000. The impact of invading alien plants on surface water resources in South Africa: a preliminary assessment. Water SA 26: 397-408.

LESLIE, A.J. \& SPOTILA, J.R. 2001. Alien plant threatens Nile crocodile (Crocodylus niloticus) breeding in Lake St. Lucia, South Africa. Biological Conservation 98: 347-355.

LOUDA, S.M., PEMBERTON, R.W., JOHNSON, M.T. \& FOLLETT, P.A. 2003. Nontarget effects - the Archilles heel of biological control? Retrospective analyses to reduce risk associated with biocontrol introductions. Annual Review of Entomology 48: 365-396.

McCONNACHIE, A.J., DE WIT, M.P., HILL, M.P. \& BYRNE, M.J. 2003. Economic evaluation of the successful biological control of Azolla filiculoides in South Africa. Biological Control 28: 25-32.

MGOBOZI, M.P., SOMERS, M.J. \& DIPPENAARSCHOEMAN, A.S. 2008. Spider responses to alien plant invasion: the effect of short- and long-term Chromolaena odorata invasion and management. Journal of Applied Ecology 45: 1189-1197.

MORAN, V.C., HOFFMANN, J.H. \& ZIMMERMANN, H.G. 2005. Biological control of invasive alien plants in South Africa: necessity, circumspection, and success. Frontiers in Ecology and the Environment 3: 77-83.

PERRINGS, C., MOONEY, H.A. \& WILLIAMSON, M. 2010. Bioinvasions and Globalization: Ecology, Economics, Management \& Policy. Oxford University Press, Oxford, U.K.

RICHARDSON, D.M. \& VAN WILGEN, B.W. 2004. Invasive alien plants in South Africa: How well do we understand the ecological impacts? South African Journal of Science 100: 45-52.

SCHOLES, R.J. \& BIGGS, R. 2005. A biodiversity intactness index. Nature 434: 45-49.

SCOTT, D.F. \& VAN WYK, D.B. 1990. The effects of wildfire on soil wettability and hydrological behaviour of an afforested catchment. Journal of Hydrology 121: 239-256.

SCOTT, D.F. \& SCHULZE, R.D. 1992. The hydrological effects of a wildfire in a eucalypt afforested catchment. South African Forestry Journal 160: 67-74.

SCOTT, D.F., VERSFELD, D.B. \& LESCH, W. 1998. Erosion and sediment yield in relation to afforestation and fire in the mountains of the Western Cape Province, South Africa. South African Geographical Journal 80: 52-59.

SHEPPARD, A.W., VAN KLINKEN, R.D. \& HEARD, T.A. 2005. Scientific advances in the analysis of direct risks of weed biological control agents to nontarget plants. Biological Control 35: 215-226.

STEENKAMP, H.E. \& CHOWN, S.L. 1996. Influence of dense stands of an exotic tree, Prosopis glandulosa Benson, on a savanna dung beetle (Coleoptera: Scarabaeinae) assemblage in southern Africa. Biological Conservation 78: 305-311.

TURPIE, J. 2004. The role of resource economics in the control of invasive alien plants in South Africa. South African Journal of Science 100: 87-93.

TURPIE, J. \& HEYDENRYCH, B. 2000. Economic consequences of alien infestation of the Cape Floral Kingdom's Fynbos vegetation. In: Perrings, C., Williamson, M. \& Dalmazzone, S. (Eds) The Economics of Biological Invasions. 152-182. Edward Elgar, Cheltenham, U.K.

VAN WILGEN, B.W. \& RICHARDSON, D.M. 1985. The effects of alien shrub invasions on vegetation structure and fire behaviour in South African fynbos shrublands: A simulation study. Journal of Applied Ecology 22: 955-966.

VAN WILGEN, B.W. \& RICHARDSON, D.M. 2010. Current and future consequences of invasion by alien species: a case study from South Africa. In: C. Perrings, C., Mooney, H. A. \& Williamson, M. (Eds) Bioinvasions and Globalization: Ecology, Economics, Management \& Policy. 183-201. Oxford University Press, Oxford, U.K.

VAN WILGEN, B.W., COWLING, R.M. \& BURGERS, C.J. 1996. Valuation of ecosystem services - A case study from South African fynbos ecosystems. BioScience $\mathbf{4 6}$ : 184-189.

VAN WILGEN, B.W., DE WIT, M.P., ANDERSON, H.J., LE MAITRE, D.C., KOTZE, I.M., NDALA, S., BROWN, B. \& RAPHOLO, M.B. 2004. Costs and benefits of biological control of invasive alien plants: case studies from South Africa. South African Journal of Science 100: 113-122.

VAN WILGEN, B.W., KHAN, A. \& MARAIS, C. 2011. Changing perspectives on managing biological invasions: insights from South Africa and the Working for Water programme. In: Richardson, D.M. (Ed.) Fifty Years of Invasion Ecology: The Legacy of Charles Elton. 377-393. Wiley-Blackwell, Oxford, U.K.

VAN WILGEN, B.W., LITTLE, P.R., CHAPMAN, R.A., GÖRGENS, A.H.M., WILLEMS, T. \& MARAIS, C. 1997. The sustainable development of water resources: history, financial costs, and benefits of alien plant control programmes. South African Journal of Science 93: 404-411.

VAN WILGEN, B.W., REYERS, B., LE MAITRE, D.C., RICHARDSON, D.M. \& SCHONEGEVEL, L. 2008. A biome-scale assessment of the impact of invasive alien plants on ecosystem services in South Africa. Journal of Environmental Management 89: 336-349.

VAN WYK, D.B. 1985. The effects of catchment management on sediment and nutrient exports in the Natal Drakensberg. In: Schulze, R.E. (Ed.) Proceedings of the 2nd South African National Hydrological Symposium. 266-274. Pietermaritzburg, South Africa.

VAN WYK, E. \& VAN WILGEN, B. W. 2002. The cost of water hyacinth control in South Africa: a case study of three options. African Journal of Aquatic Science 27: 141-149. 
VERSFELD, D.B., LE MAITRE, D.C. \& CHAPMAN, R.A 1998. Alien invading plants and water resources in South Africa: a preliminary assessment. Report TT99/98, Water Research Commission, Pretoria, South Africa.

WISE, R.M., VAN WILGEN, B.W., HILL, M.P., SCHULTHESS, F., TWEDDLE, D., CHABI-OLAY, A. \& ZIMMERMANN, H.G. 2007. The economic impact and appropriate management of selected invasive alien species on the African continent. Report
CSIR/NRE/ER/2007/0044/C, CSIR, Pretoria, South Africa.

ZIMMERMANN, H.G. 1991. Biological control of mesquite, Prosopis spp. (Fabaceae) in South Africa. Agriculture, Ecosystems and Environment 37: 175-186.

ZIMMERMANN, H.G., MORAN, V.C. \& HOFFMANN, J.H. 2004. Biological control in the management of invasive alien plants in South Africa, and the role of the Working for Water programme. South African Journal of Science 100: 34-40. 